\title{
THE PRODUCTION-SMOOTHING MODEL IS ALIVE AND WELL
}

\author{
Ray C. FAIR* \\ Yale University, New Haven, CT 06520, USA
}

Received February 1989, final version received July 1989

\begin{abstract}
Monthly data in physical units for seven industries are used to examine the production-smoothing hypothesis. The results strongly support this hypothesis. Significant effects of expected future sales on current production are found for four industries, and the estimated decision equations for all seven industries imply production-smoothing behavior. The previous negative results appear to be due to the use of data biased against the hypothesis - the shipments and inventory data of the Department of Commerce. The paper also shows that sensible results can be obtained from estimating approximations to decision equations as opposed to estimating Euler equations.
\end{abstract}

\section{Introduction}

Recent literature has been concerned with the question of whether production is smoothed relative to sales. ${ }^{1}$ Contrary to what one might expect, this does not seem to be the case, and various explanations have been offered as to what might be going on. Most of this work, however, has relied on data of questionable reliability. Miron and Zeldes (1988b), for example, using two-digit industry data, have pointed out that production data derived from the shipments and inventory data reported by the Department of Commerce do not closely match the industrial production data reported by the Board of Governors of the Federal Reserve. This conclusion was reached earlier in Fair (1969, p. 128) for four three-digit industries: Meat Products, Tires, Blast Furnace and Basic Steel Products, and Iron and Steel Foundries. ${ }^{2}$ Lack of good data may be a particularly acute problem in testing the production-smoothing hypothesis, where one is looking for differences in the paths of two series that are possibly small relative to the average levels of the paths.

\footnotetext{
*The author is indebted to Valerie Ramey and a referee for helpful comments and to Jeffrey Miron and Stephen Zeldes for supplying the Department of Commerce data.

${ }^{1}$ See, for example, Blinder (1981, 1986a, b), Blanchard (1983), West (1986), Miron and Zeldes (1988a), and Ramey (1988).

${ }^{2}$ For the Tire industry, the Department of Commerce data were compared to data reported by the Rubber Manufacturers Association. For the other three industries, the Department of Commerce data were compared to the data from the Federal Reserve.
} 
There are better data available than those from the Department of Commerce, and this paper uses some of these data. It uses monthly data in physical units for seven three- and four-digit industries to examine this hypothesis. Department of Commerce (DC) data for similar industries are also used for comparison purposes. The results using the physical-units data strongly support the production-smoothing hypothesis. ${ }^{3}$ Also, the results comparing the physical-units data to the DC data suggest that the DC data are biased against the production-smoothing hypothesis. Therefore, many of the previous negative results regarding the production-smoothing hypothesis may simply be due to the use of bad data. ${ }^{4}$

\section{The time interval}

The question of whether production is smoothed relative to sales or shipments is not independent of the length of the time interval of the data. Consider the production and shipment of a good like a candy bar. If a plant produces a fixed number of candy bars an hour when it is operating, then within the interval that the plant is continuously operating, defined say as a 'batch' run, production is surely smoothed relative to shipments, which will probably be carried out at most a few times an hour. The length of a batch run may be anywhere from a few hours to many days. Only for intervals longer than the length of a batch run is it possible that production per interval will fluctuate more than shipments per that interval. If the interval is a decade, fluctuations of production across decades are likely to be virtually identical to fluctuations of sales.

Most studies use a month as the time interval, and this is also done here. Months, however, have the unfortunate characteristic that they are not all of the same length, and adjustments need to be made for this fact. Most of the monthly data from the government are adjusted for the number of working

\footnotetext{
${ }^{3} \mathrm{~A}$ number of years ago I did a study of production behavior [Fair (1971)] that showed that expected future sales are significant determinants of current production decisions. This study used data on four of the seven industries studied in the present paper (Cigarettes, Cigars, Tires, and Cement). My initial reaction upon reading Blinder's negative results about the production-smoothing mode] was that they seemed completely at odds with my earlier results. This paper shows that this is in fact the case. The equations estimated in table 2 of this paper for the four industries are very similar to the equations estimated in table 1 in Fair (1971), and it will be seen that the equations in table 2 imply production-smoothing behavior. To some extent the results in table 2 for the four industries are simply updates of the results in table 1 of my earlier study.

${ }^{4} \mathrm{~A}$ possible exception to this is the study of Blanchard (1983), which uses highly disaggregated data - data at the automobile division level - and rejects the production-smoothing hypothesis. It is the case, however, that the automobile industry is characterized by a complicated set of relationships between producers and dealers (who hold most of the inventories), and it is not clear that the standard production-smoothing model captures these relationships very well. At any rate, Blanchard's results are at odds with the production-smoothing hypothesis under the assumptions that he makes about the relationships between producers and dealers.
} 
days in the month. For example, in computing the industrial production index, the Federal Reserve Board (FRB) estimates the number of working days in each month in each industry and divides the production figures by the number of working days to put them on a daily rate basis. The physical-units data collected for this study have not been adjusted for the number of working days, and so the FRB adjustment was applied to the data. In addition, as will be seen, for two industries - Cigarettes and Cigars - adjustment was made for the fact that many firms in the two industries shut down for vacations in July and December.

The main question examined in this paper is thus whether the average rate of production per month fluctuates more or less than the average rate of sales per month. It turns out, however, that the overall results are not sensitive to the use of rates instead of levels.

\section{A preliminary examination of the data}

Let $Y_{t}$ denote the level of production in month $t$, let $S_{t}$ denote the level of sales or shipments in month $t$, and let $V_{t}$ denote the stock of inventories at the end of month $t .^{5}$ By definition, production equals sales plus the change in inventories:

$$
Y_{t}=S_{t}+\left(V_{t}-V_{t-1}\right)
$$

Monthly data in physical units on at least two of these three variables are available for the Cigarette, Cigar, Tire, Cement, Copper Refining, Lead Refining, and Slab Zinc industries in the United States. (Data sources are presented in the appendix.) For three industries - Tires, Lead Refining, and Slab Zinc - data on all three variables are available. None of the data used in this study are seasonally adjusted. It seems to make little sense to seasonally adjust the data when testing the production-smoothing hypothesis. The hypothesis is about actual changes in production, sales, and inventories, not seasonally adjusted changes.

Data on the number of working days in a week for each industry are available from the FRB. Given these data and given a calendar for each year, one can compute the number of working days in each month for each industry. $D_{t}$ will be used to denote the number of working days in month $t$ for the given industry.

\footnotetext{
${ }^{5}$ For the Department of Commerce data inventories include finished goods inventories plus work in progress. For the physical-units data there is no breakdown between finished goods and work in progress. Given the nature of the products (cigarettes, cigars, tires, cement, refined copper, refined lead, and slab zinc), it is probably the case that the amount of inventories held as work in progress is small relative to the total amount held.
} 
For the Cigarette and Cigar industries, data on $Y_{t}$ and $S_{t}$ are available, and data on $V_{t}$ were constructed using eq. (1) and a benchmark value for $V$. For the Cement and Copper Refining industries, data on $Y_{t}$ and $V_{t}$ are available, and data on $S_{t}$ were constructed using eq. (1). For the other three industries, where data on all three variables are available, eq. (1) does not hold exactly (life is never simple), and so at least one variable is measured with error. For each of these industries, three sets of data were used. For the first set, the data on $Y_{t}$ and $V_{t}$ were used to construct data on sales using eq. (1). Let $S S_{t}$ denote this computed sales variable. For the second set, the data on $Y_{t}$ and $S_{t}$ were used to construct data on the stock of inventories using eq. (1) and an initial benchmark value for the stock of inventories. Let $V V_{t}$ denote this computed inventory stock variable. For the third set, the data on $S_{t}$ and $V_{t}$ were used to construct data on production using eq. (1). Let $Y Y_{t}$ denote this computed value of production. The following equations thus hold for these three industries:

$$
\begin{aligned}
& Y_{t}=S S_{t}+\left(V_{t}-V_{t-1}\right), \\
& Y_{t}=S_{t}+\left(V V_{t}-V V_{t-1}\right), \\
& Y Y_{t}=S_{t}+\left(V_{t}-V_{t-1}\right) .
\end{aligned}
$$

Adjustments to $D_{t}$ were made for the Cigarette and Cigar industries for the months of July and December. Plots of the data for $Y_{t}$ for these two industries show large declines in output in July and December. From personal interviews with production managers of firms in these two industries, it was determined that these declines reflect vacation shutdowns for a week or two by many firms in the industries. Shutdown days are nonworking days (like Saturdays and Sundays for industries that do not work these days), and they should not be counted in $D_{t}$. In order to adjust for shutdowns, estimates are needed of the average number of shutdown days in July and December. These estimates were obtained as follows.

Consider July for the Cigarette industry. Monthly data were collected from 1952 through 1987 (26 years). For each year $Q=\left(Y_{\text {June }} / D_{\text {June }}+Y_{\text {Aug. }} / D_{\text {Aug. }}\right) / 2$ was computed. Let $R_{\text {July }}=Y_{\text {July }} / Q . R_{\text {July }}$ would be the number of working days in July in the year in question if the rate of production in July were the same as the average rate in June and August. If $D_{\mathrm{July}}$ is the number of working days in July not adjusting for vacations (data from the FRB), then $Z_{\text {Juty }}=$ $D_{\text {July }}-R_{\text {July }}$ is the estimated number of vacation shutdown days in July in the given year. Although it is unrealistic to assume in any one year that the July rate of production is the same as the average rate in June and August, this is probably not an unrealistic assumption across many years. With 26 years worth of data, 26 values of $R_{\text {July }}$ and then $Z_{\text {July }}$ can be computed. Let $\hat{Z}_{\text {July }}$ 
denote the average of these 26 values. $\hat{Z}_{\text {July }}$ was taken to be the estimate of the number of vacation shutdown days in July. Given this value, $D_{\text {July }}$ for a given year was taken to be the number of working days in July of that year before adjustment minus $\hat{Z}_{\text {July. }}$ A similar procedure was followed for December, where $Q$ in this case is $\left(Y_{\mathrm{Nov}} / D_{\mathrm{Nov}}+Y_{\mathrm{Jan} .} / D_{\mathrm{Jan} .}\right) / 2$. This procedure was also followed for the Cigar industry. For Cigarettes the estimated adjustment for July was 4.07 days, with a standard error of 1.22 days, and the estimated adjustment for December was 5.02 days, with a standard error of 1.71 days. For Cigars the estimated adjustments were 6.03 and 5.92 days, respectively, with standard errors of 1.58 and $1.72 .^{6}$

It should be stressed that adjusting for vacations in the above way begs the question of why firms shut down for vacations in July and December. This pattern, for example, may reflect nonconvexities in technology or in workers' preferences, which in principle should be modeled, or it may primarily be historical accident. Whatever the case, the adjustment does not dramatically influence the results, and it is only made for two of the seven industries. Similarly, as noted above, the results are not sensitive to the adjustment for the number of working days in the month.

DC data on production and shipments were obtained from Miron and Zeldes (1988b). Data for four industries were used here - Tobacco; Rubber; Stone, Clay, and Glass; and Primary Metals. Cigarettes and Cigars are in the Tobacco industry (and in fact make up almost all of the Tobacco industry); Tires are in the Rubber industry; Cement is in the Stone, Clay, and Glass industry; and Refined Copper, Refined Lead, and Slab Zinc are in the Primary Metals industry. The production data were derived from data on shipments and inventories (including work in progress inventories). For present purposes the nonseasonally adjusted data were used. The data were available from February 1959 through December 1984.

The first question to ask of the data is whether the variance of production is greater than or less than the variance of shipments. As in Blinder (1986a) and Miron and Zeldes (1988b), the variables were detrended first. ${ }^{7}$ The results are presented in table 1 . Consider the results for the physical-units data first. Results for two sample periods are presented: the longest sample period

\footnotetext{
${ }^{6}$ The estimates were not rounded to the nearest integer because it is not the case that all firms in the industries shut down for the same number of days.

${ }^{7}$ The same procedure was used here as was used in Blinder (1986a) and Miron and Zeldes (1988b). The $\log$ of each variable was regressed on a constant and time. The coefficients were estimated by GLS under the assumption of a second-order autoregressive process of the error term. The antilogs of the fitted values of this regression were then subtracted from the actual values to create the detrended data. The estimates of the coefficient of the time trend were insignificant for Copper Refining and Lead Refining, and so no detrending was done for these two industries. The estimates for the time trend for Cigars and Slab Zinc were negative (and significant). The estimation period used for the detrending was always the same as the sample period used to compute the variance ratios.
} 


\section{Table 1}

Ratio of the variance of detrended production to the variance of detrended sales.

\begin{tabular}{|c|c|c|c|c|}
\hline Industry & Sample period & $\begin{array}{l}\text { Data } \\
\text { used }^{\mathrm{a}}\end{array}$ & $\begin{array}{l}\text { Monthly } \\
\text { levels }^{b}\end{array}$ & $\begin{array}{l}\text { Daily } \\
\text { rates }^{\circ}\end{array}$ \\
\hline \multicolumn{5}{|c|}{ Physical-units data } \\
\hline Cigarettes & $\begin{array}{l}52.04-88.08 \\
59.01-84.12\end{array}$ & (b) & $\begin{array}{l}1.020 \\
1.206\end{array}$ & $\begin{array}{l}0.758 \\
0.857\end{array}$ \\
\hline Cigars & $\begin{array}{l}52.04-88.08 \\
59.02-84.12\end{array}$ & (b) & $\begin{array}{l}1.128 \\
1.042\end{array}$ & $\begin{array}{l}1.067 \\
0.943\end{array}$ \\
\hline Tires & $\begin{array}{l}47.04-87.06 \\
59.02-84.12\end{array}$ & $\begin{array}{l}\text { (a) } \\
\text { (b) } \\
\text { (c) } \\
\text { (a) } \\
\text { (b) } \\
\text { (c) }\end{array}$ & $\begin{array}{l}0.872 \\
1.120 \\
0.910 \\
0.881 \\
1.070 \\
0.978\end{array}$ & $\begin{array}{l}0.892 \\
1.151 \\
0.936 \\
0.907 \\
1.105 \\
1.010\end{array}$ \\
\hline Cement & $\begin{array}{l}47.04-64.12 \\
59.02-64.12\end{array}$ & $\begin{array}{l}\text { (a) } \\
\text { (a) }\end{array}$ & $\begin{array}{l}0.365 \\
0.535\end{array}$ & $\begin{array}{l}0.354 \\
0.527\end{array}$ \\
\hline Copper Refining & $\begin{array}{l}47.04-87.12 \\
59.02-84.12\end{array}$ & $\begin{array}{l}\text { (a) } \\
\text { (a) }\end{array}$ & $\begin{array}{l}0.890 \\
0.876\end{array}$ & $\begin{array}{l}0.886 \\
0.874\end{array}$ \\
\hline Lead Refining & $\begin{array}{l}47.04-87.12 \\
59.02-84.12\end{array}$ & $\begin{array}{l}\text { (a) } \\
\text { (b) } \\
\text { (c) } \\
\text { (a) } \\
\text { (b) } \\
\text { (c) }\end{array}$ & $\begin{array}{l}0.831 \\
0.759 \\
0.942 \\
0.854 \\
0.814 \\
0.964\end{array}$ & $\begin{array}{l}0.832 \\
0.761 \\
0.939 \\
0.855 \\
0.816 \\
0.961\end{array}$ \\
\hline Slab Zinc & $\begin{array}{l}47.04-87.12 \\
59.02-84.12\end{array}$ & $\begin{array}{l}\text { (a) } \\
\text { (b) } \\
\text { (c) } \\
(a) \\
\text { (b) } \\
\text { (c) }\end{array}$ & $\begin{array}{l}0.926 \\
0.907 \\
0.950 \\
0.862 \\
0.846 \\
0.874\end{array}$ & $\begin{array}{l}0.916 \\
0.899 \\
0.947 \\
0.858 \\
0.844 \\
0.869\end{array}$ \\
\hline \multicolumn{5}{|c|}{ Department of Commerce data } \\
\hline $\begin{array}{l}\text { Tobacco } \\
\text { Rubber } \\
\text { Stone, Clay, Glass } \\
\text { Primary Metals }\end{array}$ & $\begin{array}{l}59.02-84.12 \\
59.02-84.12 \\
59.02-84.12 \\
59.02-84.12\end{array}$ & $\begin{array}{l}\text { (c) } \\
(c) \\
(c) \\
(c)\end{array}$ & . & $\begin{array}{l}3.115 \\
1.115 \\
0.708 \\
1.011\end{array}$ \\
\hline
\end{tabular}

a) Production and inventories and definition for sales.

(b) Production and sales and definition for inventories.

(c) Sales and inventories and definition for production.

${ }^{b}$ Monthly level means that data on production and sales were the total amounts produced and sold during the month.

${ }^{\circ}$ Daily rate means that the data on production and sales were the average amounts produced and sold per working day during the month. 
allowed by the data and the sample period corresponding to the period used for the DC data. The results are quite striking, given the recent results in the literature. For the data in daily rates, only in one case for the Cigar industry and in three cases for the Tire industry is the variance of production greater than the variance of sales. Otherwise, the ratio of the variance of production to the variance of sales varies from 0.354 to 0.943 . Similar results hold for production and sales not divided by $D_{t}$ (under the heading 'monthly levels') except for the Cigarette industry and in one case each for the Cigar and Tire industries, where not adjusting for the number of working days reverses the result. The overall results using the physical-units data thus provide strong support for the production-smoothing hypothesis.

Consider now the results for the DC data. For three of the four industries the variance of production is greater than the variance of sales, although the ratio for one of the three - Primary Metals - is very close to one. It is useful to compare these results to those in table 3 in Miron and Zeldes (1988b) (MZ). They differ from the MZ results because the sample period is longer here (ending in December 1984 rather than in July 1981) and because seasonally unadjusted data have been used. For Stone, Clay, and Glass the ratios are 0.708 here and 1.12 in MZ. This difference is primarily due to the use of seasonally unadjusted data. There are large seasonals for Stone, Clay, and Glass, and production appears to be smoothed relative to sales in the unadjusted data. For Tobacco the ratios are 3.115 here and 2.43 in MZ, both very large numbers. For Rubber the ratios are very similar -1.115 here and 1.13 in MZ. Finally, for Primary Metals the ratios are 1.011 here and 0.96 in MZ. These two ratios are fairly close, although on the opposite sides of one. It is interesting to note that Primary Metals is the only industry in table 3 in MZ in which the ratio is less than one. In the seasonally unadjusted data it is slightly greater than one.

What do the results in table 1 say about the DC data? First, for the three industries where data on production, sales, and inventories are available - Tires, Lead Refining, and Slab Zinc - production is less smooth relative to sales when it is computed from the identity - row (c) - than when the level of sales is computed from the identity - row (a). [It is also the case that production is less smooth relative to sales in row (c) than in row (b) for Lead Refining and Slab Zinc, but not for Tires. $\left.{ }^{8}\right]$ These results suggest that measurement errors are such as to add additional noise to the computed variables. Since production is the computed variable in the DC data, this may be an important reason that the DC data tend to show production noisier than sales.

\footnotetext{
${ }^{8} 1$ don't know why row (b) for Tires, which uses direct data on both production and sales, is at odds with the other two rows for this industry [row (b) having sales smoother than production]. In many months the identity is far from being met for this industry, and so there are clearly large measurement errors somewhere.
} 
Second, one can make at least a rough comparison of the physical-units results and the DC results in table 1 . The DC results for Tobacco seem particularly bad. The ratio is 3.115 , which compares to 0.857 for Cigarettes and 0.943 for Cigars. The physical-units data for Cigarettes and Cigars, which are IRS data, seem fairly good, which suggests that the DC data for Tobacco are heavily biased against production smoothing. The DC ratio for Rubber is 1.115, which compares to 1.010 for Tires [using row (c)], for a difference of 0.105 . The DC ratio for Stone, Clay, and Glass is 0.708 , which compares to 0.527 for Cement, for a difference of 0.181 . Finally the DC ratio for Primary Metals is 1.011, which compares to 0.874 for Copper Refining, 0.961 for Lead Refining [using row (c)], and 0.869 for Slab Zinc [using row (c)], for differences of $0.137,0.050$, and 0.142 . The DC ratios for these three industries thus appear on average to be biased upward by a little over 10 percent, assuming that the physical-units results are about right, although this estimate is obviously very crude.

Note that the $\mathrm{DC}$ ratios are larger than the physical-units ratios even when the latter are also based on computed production data - row (c) for Tires, Lead Refining, and Slab Zinc. The DC data are thus likely to be biased against production smoothing on two counts. First, the production data are computed from the shipments and inventory data. Second, even holding the way production is computed constant, the DC data show production noisier relative to shipments than do the physical-units data.

The conclusion from table 1 that the physical-units data support the production-smoothing hypothesis is generally consistent with the results in Ghali (1987), Krane and Braun (1989), and Dimelis and Kollintzas (1989). Ghali's results are based on cement data by district and on data from five other industries. Ghali finds that nonseasonally adjusted detrended output is less variable than shipments in 18 of the 19 cement districts and in three of the other five industries (table 1, p. 466). Krane and Braun examine physical-units data for 38 industries and find that the variance of production is less than the variance of shipments in 21 of the 38 cases. Of the other 17 cases, 10 are accounted for by agricultural and lumber products. Dimelis and Kollintzas use physical-units data and find evidence of production smoothing in the petroleum industry (p. 120, fn. 9). The results from these three studies thus add support to the view that the negative results concerning the production-smoothing hypothesis are due to the use of poor data. ${ }^{9}$

\footnotetext{
${ }^{9}$ It should be noted, however, that the sample period used by Krane and Braun (1989) - January 1977 to July 1986 - is considerably shorter than the sample periods used here, and so less confidence can be placed on these results. Ghali's (1987) sample period is also fairly short, covering only data from the 1950's. Dimelis and Kollintzas (1989) use annual data for the 1947-1984 period.
} 


\section{Estimated decision equations}

In examining the production decision of a representative firm, the standard approach in the literature is to assume that a firm chooses production, given sales, to minimize the expected present discounted value of costs,

$$
L=\mathrm{E}_{t} \sum_{i=1}^{\infty} \beta^{i} C_{t+i}
$$

subject to eq. (1), where $C_{t+i}$ is the cost in period $t+i$ and $\beta$ is the discount factor. $E_{t}$ is the expectations operator conditional on information available at time $t . C_{t+i}$ is usually taken to be a function of $y_{t+i}, y_{t+i-1}, s_{t+i}$, and $V_{t+i-1}::^{10}$

$$
C_{t+i}=f\left(y_{t+i}, y_{t+i-1}, s_{t+i}, V_{t+i-1}\right) .
$$

Given a specification for $f$, given $y_{t-1}$ and $V_{t-1}$, and given the conditional distributions of the current and future values of $s$, it is possible in principle to solve for the optimal value of $y_{t}$, which will be denoted $y_{t}^{0}$.

It is generally not possible to derive an analytic expression for $y_{t}^{0}$, and other approaches are needed. One approach is to estimate the parameters of the cost function from the first-order conditions. While this approach is currently popular, it has the disadvantage of requiring a parametric specification of the cost function. ${ }^{11}$ Also, it is usually not possible to back out the decision equations once the first-order conditions have been estimated.

An alternative approach, which is followed here, is to estimate approximations to the decision equations. The procedure is as follows. First, the random variables $s_{t+i}, i=0,1$, are replaced by their expected values, $\mathrm{E}_{t} s_{t+i}, i=$ $0,1, \ldots$. It is a common procedure in the engineering literature to replace random variables with their expected values to make the problem tractable. In the case of a quadratic objective function and a linear model, this replacement results in no loss because certainty equivalence holds. Otherwise, there is some loss, but many problems may be close enough to the linear-quadratic case for the loss to be fairly small.

Given this replacement in the present context, one can write the decision equation for current-period production as

$$
y_{t}^{0}=f\left(y_{t-1}, V_{t-1}, \mathrm{E}_{t} s_{t}, \mathrm{E}_{t} s_{t+1}, \mathrm{E}_{t} s_{t+2}, \ldots, \alpha\right),
$$

\footnotetext{
${ }^{10} \mathrm{See}$, for example, Ramey (1988). In what follows $y$ denotes the daily rate of production and $s$ denotes the daily rate of sales. In this notation the identity (1) is $y_{t} D_{t}=s_{t} D_{t}+V_{t}-V_{t-1}$.

${ }^{11}$ Krane and Braun (1989) report that their attempts to estimate Euler equations using physical-units data were unsuccessful.
} 
where $\alpha$ is the vector of parameters of the cost function. Eq. (4) states that the optimal value of production for period $t$ is a function of $y_{t-1}, V_{t-1}$, and expected future sales. The functional form of (4) is generally not known. The aim of the empirical work is to estimate equations that are approximations of (4). One part of the empirical work is to find measures for the expected values, and the other part is to choose the functional form. It is not possible to recover the parameters of the cost function using this approach, but it is possible, as will be seen below, to examine whether the estimated equation implies production-smoothing behavior. The estimated residuals from the estimation work can be interpreted as errors approximating the true decision equations and the true expectation-formation mechanism.

For the work below eq. (4) is assumed to be linear. Two expectational hypotheses are examined. For both hypotheses it is assumed that firms know current sales: $\mathrm{E}_{t} s_{t}=s_{t}$. The first hypothesis, hypothesis A, is that firms expect a future month's sales to be the same as the sales in the same month a year ago: $\mathrm{E}_{t} s_{t+i}=s_{t+i-12}$. The second hypothesis, hypothesis $\mathrm{B}$, is that firms form expectations rationally and that there is an observed vector of variables (observed by the econometrician), denoted $Z_{t}$, that is used in part by firms in forming their (rational) expectations. The estimation work below does not require for consistent estimates that $Z_{t}$ include all the variables used by firms in forming their expectations. $Z_{t}$ was taken to include the constant term, a linear time trend, $V_{t-1}, y_{t-1}, s_{t-i}, i=0,1, \ldots 12$, and eleven seasonal dummies. The lead length for both hypotheses was taken to be six months.

Under hypothesis $\mathrm{A}$ the equation was estimated by ordinary least squares, and under hypothesis B the equation was estimated using Hansen's (1982) method-of-moments estimator, ${ }^{12}$

\footnotetext{
${ }^{12}$ Hansen's method as used in this paper is the following. The actual future values of sales are used on the right-hand side of the equation, and the equation is first estimated by two-stage least squares (2SLS). The estimated residuals from this equation are used to create Hansen's $M$ matrix under the assumption of a fifth-order moving average of the error term (fifth-order because there are leads of six in the equation). Hansen's estimator is then
}

$$
\left(X^{\prime} Z M^{-1} Z^{\prime} X\right)^{-1} X^{\prime} Z M^{-1} y \text {, }
$$

with estimated covariance matrix

$$
T\left(X^{\prime} Z M^{-1} Z^{\prime} X\right)^{-1},
$$

where $X$ is the matrix of explanatory variables (including the future sales variables), $Z$ is the matrix of first-stage regressors, $y$ is the left-hand-side variable, and $T$ is the number of observations. $M$ is estimated as follows. Let

$$
a_{j}=(T-j)^{-1} \sum_{i=j}^{T} v_{\mathrm{i}} v_{\mathrm{r}-j} \text { and } B_{j}=(T-j)^{-1} \sum_{t=j}^{T} Z_{\mathrm{r}} Z_{\mathrm{r}-j}, \quad j=0,1, \ldots, J,
$$

where $v_{t}$ is the estimated residual for period $t$ from the 2SLS regression and $J$ is the order of the moving average (five in the present case). The estimate of $\mathrm{M}$ is then $\left(a_{0} B_{0}+a_{1} B_{1}+a_{1} B_{1}^{\prime}\right.$ $\left.+\cdots+a_{J} B_{f}+a_{J} B_{J}^{\prime}\right)$. See Hayashi and Sims (1983) for a discussion of this way of estimating $M$. The more general way of estimating $M$ did not produce sensible results. 
As the model has been set up so far, there are no sign or size restrictions on the coefficients. The following specification leads to some restrictions, and it will be useful to examine the coefficient estimates within this framework. Let $V_{t}^{*}$ denote the firm's long-run desired stock of inventories. $V_{t}^{*}$ is assumed to be a function of $s_{i}$ :

$$
V_{t}^{*}=\beta_{0}+\beta_{1} s_{t}, \quad \beta_{1}>0
$$

Let $y_{t}^{*}$ denote the firm's desired rate of production in period $t$ if there were no costs of adjusting production. $y_{t}^{*}$ is assumed to be determined as

$$
\begin{array}{r}
y_{t}^{*}=s_{t}+\gamma_{0}\left(V_{t}^{*}-V_{t-1}\right)+\sum_{i=1}^{n} \gamma_{i}\left(\mathrm{E}_{t} s_{t+i}-\mathrm{E}_{t} s_{t+i-1}\right), \\
\gamma_{i}>0, \quad i=0,1, \ldots, n .
\end{array}
$$

Eq. (6) states that a desired stock of inventories greater than the actual stock leads the firm, other things being equal, to produce more than it sells (so as to build the stock back up). Also, if sales are expected to increase in the future, this leads the firm, other things being equal, to produce more than it sells (so it can meet some of the increased future sales by selling out of inventories). ${ }^{13}$ If the actual stock of inventories is equal to the desired stock and if sales are not expected to change in the future, then desired production is simply equal to current sales.

If there are costs of changing production, actual production may differ from desired production. Actual production is assumed to be

$$
y_{t}-y_{t-1}=\lambda\left(y_{t}^{*}-y_{t-1}\right), \quad 0<\lambda<1 .
$$

Eq. (7) is a standard partial-adjustment equation. Combining eqs. (5), (6), and (7) yields

$$
\begin{aligned}
y_{t}-y_{t-1}= & \lambda \gamma_{0} \beta_{0}+\lambda\left(s_{t}-y_{t-1}\right)+\lambda \gamma_{0} \beta_{1} s_{t}-\lambda \gamma_{0} V_{t-1} \\
& +\lambda \sum_{i=1}^{n} \gamma_{i}\left(\mathrm{E}_{t} s_{t+i}-\mathrm{E}_{t} s_{t+i-1}\right) .
\end{aligned}
$$

Estimating eq. (8) is the same as estimating an equation with $y_{t}$ on the left-hand side and the constant term, $y_{t-1}, V_{t-1}, s_{t}$, and $\mathrm{E}_{t} s_{t+i}(i=1, \ldots, n)$

\footnotetext{
${ }^{13}$ This is a good place to see why the use of daily rates is preferred to the use of levels in the estimation work. If sales are expected to change from one month to the next simply because there is a different number of working days in the two months, this is quite different from the case where the daily rate of sales is expected to change.
} 
on the right-hand side. (Remember that $\mathrm{E}_{t} s_{t}=s_{t}$ by assumption for both exceptional hypotheses.) This latter equation is simply the linear version of eq. (4) with $\mathrm{E}_{t} s_{t}=s_{t}$. Eq. (8) thus imposes no restrictions on the linearized version of eq. (4). The advantage of estimating the equation in the form of (8) is that the coefficients have some interpretation. This interpretation will, of course, be wrong if eqs. (5)-(7) are poor approximations, but at least eq. (8) provides an initial framework. The key question here is whether the estimated decision equations imply production-smoothing behavior, and the examination of this question below is valid even if the interpretation of the coefficients in eq. (8) is wrong.

The results of estimating eq. (8) are presented in table $2 .{ }^{14}$ Consider first the results using the physical-units data, which are the most trustworthy. They are as follows.

(1) The estimates of $\lambda$ are all significantly less than one (and greater than zero), which supports the partial-adjustment eq. (7).

(2) All the estimates of $\lambda \gamma_{0}$ (and thus the implied estimates of $\gamma_{0}$ ) are positive as expected.

(3) The implied estimate of $\beta_{1}$ is negative for three industries - Cigarettes, Copper Refining, and Lead Refining. At least for these three industries, eq. (5) is rejected, and $V_{t}^{*}$ must be a function of other than just the current level of sales.

(4) The expected future sales variables are highly significant for Cigarettes, Cigars, Tires, and Cement. For these four industries the two expectational hypotheses lead to roughly the same results, with perhaps a slight edge to hypothesis B. The expected future sales variables are not significant for the other three industries. For these three industries the $F$ test of the hypothesis that all the expected future sales variables have coefficients of zero is not rejected under expectations hypothesis A.

(5) The hypothesis of structural stability between the two halves of the sample was tested for each equation using a Wald test. ${ }^{15}$ The hypothesis was rejected for Cigarettes and Cement under both expectational hypotheses and for Slab Zinc under hypothesis A.

(6) Looking at the overall results for a given industry, the results for Tires are quite good. They provide strong indirect support for eqs. (5)-(7). Note that expected future sales as far as six months ahead significantly affect current production decisions. The results for Cement are also quite good except for the structural stability test. Results for the Cement industry are based only on 195 observations, which may not be enough to provide a reliable test of structural

\footnotetext{
${ }^{14}$ For the three industries in which data on production, sales, and inventories were available, the data on production and inventories were used and the level of sales was computed from the identity - row (a) in table 1.

${ }^{15}$ See Andrews and Fair (1988) for a discussion of this test.
} 
Table 2

Equation estimates ( $t$-statistics in absolute value are in parentheses). ${ }^{\mathrm{a}}$

$$
y_{t}-y_{t-1}=\lambda \gamma_{0} \beta_{0}+\lambda\left(s_{t}-y_{t-1}\right)-\lambda \gamma_{0} V_{t-1}+\lambda \gamma_{0} \beta_{1} s_{t}+\lambda \sum_{i=1}^{n} \gamma_{i}\left(\mathrm{E}_{t} s_{t+i}-\mathrm{E}_{t} s_{t+i-1}\right) \text {. }
$$

\begin{tabular}{|c|c|c|c|c|c|c|c|c|c|c|c|c|c|c|}
\hline \multirow{2}{*}{$\begin{array}{l}\text { Estimates } \\
\text { of: }\end{array}$} & \multicolumn{2}{|c|}{ Cigarettes } & \multicolumn{2}{|c|}{ Cigars } & \multicolumn{2}{|c|}{ Tires } & \multicolumn{2}{|c|}{$\begin{array}{c}\text { Physical-units data } \\
\text { Cement }\end{array}$} & \multicolumn{2}{|c|}{$\begin{array}{l}\text { Copper } \\
\text { Refining, }\end{array}$} & \multicolumn{2}{|c|}{$\begin{array}{l}\text { Lead } \\
\text { Refining }\end{array}$} & \multicolumn{2}{|c|}{ Slab Zinc } \\
\hline & (A) & (B) & (A) & (B) & (A) & (B) & (A) & (B) & (A) & (B) & (A) & (B) & (A) & (B) \\
\hline$\lambda \gamma_{0} \boldsymbol{\beta}_{0}$ & $\begin{array}{c}645.5 \\
(4.10)\end{array}$ & $\begin{array}{c}488.8 \\
(4.73)\end{array}$ & $\begin{array}{c}1.74 \\
(0.38)\end{array}$ & $\begin{array}{c}-8.16 \\
(1.98)\end{array}$ & $\begin{array}{c}-6.80 \\
(0.67)\end{array}$ & $\begin{array}{c}-40.75 \\
(3.04)\end{array}$ & $\begin{array}{l}69.5 \\
(3.55)\end{array}$ & $\begin{array}{c}127.9 \\
(4.51)\end{array}$ & $\begin{array}{c}273.7 \\
(2.24)\end{array}$ & $\begin{array}{l}182.3 \\
(0.86)\end{array}$ & $\begin{array}{c}146.4 \\
(3.00)\end{array}$ & $\begin{array}{c}143.7 \\
(2.09)\end{array}$ & $\begin{array}{c}-1.61 \\
(0.11)\end{array}$ & $\begin{array}{c}-1.10 \\
(0.08)\end{array}$ \\
\hline$\lambda$ & $\begin{array}{r}0.817 \\
(32.57)\end{array}$ & $\begin{array}{r}0.852 \\
(34.77)\end{array}$ & $\begin{array}{r}0.553 \\
(16.73)\end{array}$ & $\begin{array}{r}0.683 \\
(18.17)\end{array}$ & $\begin{array}{r}0.441 \\
(11,00)\end{array}$ & $\begin{array}{r}0.662 \\
(13.80)\end{array}$ & $\begin{array}{r}0.556 \\
(23.23)\end{array}$ & $\begin{array}{r}0.530 \\
(19.45)\end{array}$ & $\begin{array}{r}0.597 \\
(19.46)\end{array}$ & $\begin{array}{r}0.602 \\
(18.51)\end{array}$ & $\begin{array}{r}0.350 \\
(11.03)\end{array}$ & $\begin{array}{l}0.366 \\
(5.97)\end{array}$ & $\begin{array}{r}0.204 \\
(8.91)\end{array}$ & $\begin{array}{r}0.219 \\
(7.66)\end{array}$ \\
\hline$\lambda \gamma_{0}$ & $\begin{array}{l}0.00376 \\
(3.99)\end{array}$ & $\begin{array}{l}0.00291 \\
(4.71)\end{array}$ & $\begin{array}{l}0.000357 \\
(1.91)\end{array}$ & $\begin{array}{l}0.000083 \\
(0.53)\end{array}$ & $\begin{array}{l}0.00159 \\
(3.21)\end{array}$ & $\begin{array}{l}0.00288 \\
(4.66)\end{array}$ & $\begin{array}{l}0.00282 \\
(4.90)\end{array}$ & $\begin{array}{l}0.00425 \\
(5.45)\end{array}$ & $\begin{array}{l}0.000252 \\
(1.71)\end{array}$ & $\begin{array}{l}0.000249 \\
(1.44)\end{array}$ & $\begin{array}{l}0.000440 \\
(2.70)\end{array}$ & $\begin{array}{l}0.000453 \\
(3.02)\end{array}$ & $\begin{array}{l}0.000163 \\
(1.83)\end{array}$ & $\begin{array}{l}0.000257 \\
(2.44)\end{array}$ \\
\hline$\lambda \gamma_{v} \beta_{1}$ & $\begin{array}{r}-0.030 \\
(2.65)\end{array}$ & $\begin{array}{r}-0.020 \\
(2.78)\end{array}$ & $\begin{array}{r}0.007 \\
(0.50)\end{array}$ & $\begin{array}{r}0.034 \\
(2.74)\end{array}$ & $\begin{array}{r}0.117 \\
(2.68)\end{array}$ & $\begin{array}{r}0.251 \\
(4.51)\end{array}$ & $\begin{array}{r}0.190 \\
(4.82)\end{array}$ & $\begin{array}{r}0.300 \\
(5.48)\end{array}$ & $\begin{array}{r}-0.053 \\
(2.01)\end{array}$ & $\begin{array}{r}-0.032 \\
(0.67)\end{array}$ & $\begin{array}{r}-0.078 \\
(2.69)\end{array}$ & $\begin{array}{r}-0.075 \\
(1.68)\end{array}$ & $\begin{array}{r}0.005 \\
(0.68)\end{array}$ & $\begin{array}{r}0.009 \\
(1.21)\end{array}$ \\
\hline$\lambda \gamma_{1}$ & $\begin{array}{r}0.147 \\
(5.56)\end{array}$ & $\begin{array}{r}0.180 \\
(6.96)\end{array}$ & $\begin{array}{r}0.071 \\
(2.72)\end{array}$ & $\begin{array}{r}0.292 \\
(6.32)\end{array}$ & $\begin{array}{r}0.290 \\
(6.52)\end{array}$ & $\begin{array}{r}0.665 \\
(8.65)\end{array}$ & $\begin{array}{r}0.279 \\
(7.50)\end{array}$ & $\begin{array}{c}0.392 \\
(8.11)\end{array}$ & $\begin{array}{c}0.027 \\
(1.07)\end{array}$ & $\begin{array}{r}0.024 \\
(0.30)\end{array}$ & $\begin{array}{r}0.021 \\
(0.63)\end{array}$ & $\begin{array}{r}0.069 \\
(0.58)\end{array}$ & $\begin{array}{c}0.033 \\
(1.65)\end{array}$ & $\begin{array}{r}0.079 \\
(1.48)\end{array}$ \\
\hline$\lambda \gamma_{2}$ & $\begin{array}{r}0.056 \\
(1.96)\end{array}$ & $\begin{array}{l}0.026 \\
(0.97)\end{array}$ & $\begin{array}{l}0.060 \\
(1.83)\end{array}$ & $\begin{array}{r}0.195 \\
(4.44)\end{array}$ & $\begin{array}{r}0.252 \\
(5.34)\end{array}$ & $\begin{array}{r}0.471 \\
(6.66)\end{array}$ & $\begin{array}{r}0.269 \\
(7.56)\end{array}$ & $\begin{array}{r}0.313 \\
(6.62)\end{array}$ & $\begin{array}{r}0.019 \\
(0.58)\end{array}$ & $\begin{array}{r}0.061 \\
(0.80)\end{array}$ & $\begin{array}{c}0.014 \\
(0.36)\end{array}$ & $\begin{array}{r}-0.117 \\
(0.81)\end{array}$ & $\begin{array}{c}0.033 \\
(1.42)\end{array}$ & $\begin{array}{c}0.072 \\
(1.38)\end{array}$ \\
\hline$\lambda \gamma_{3}$ & $\begin{array}{r}-0.004 \\
(0.12)\end{array}$ & $\begin{array}{r}-0.061 \\
(2.22)\end{array}$ & $\begin{array}{r}0.037 \\
(1.09)\end{array}$ & $\begin{array}{r}0.089 \\
(1.96)\end{array}$ & $\begin{array}{r}0.175 \\
(3.99)\end{array}$ & $\begin{array}{r}0.429 \\
(6.85)\end{array}$ & $\begin{array}{r}0.128 \\
(4.06)\end{array}$ & $\begin{array}{r}0.196 \\
(4.94)\end{array}$ & $\begin{array}{r}0.033 \\
(1.02)\end{array}$ & $\begin{array}{r}0.117 \\
(1.59)\end{array}$ & $\begin{array}{r}-0.020 \\
(0.51)\end{array}$ & $\begin{array}{r}0.133 \\
(0.92)\end{array}$ & $\begin{array}{r}0.016 \\
(0.72)\end{array}$ & $\begin{array}{r}0.001 \\
(0.03)\end{array}$ \\
\hline$\lambda \gamma_{4}$ & $\begin{array}{r}0.079 \\
(2.74)\end{array}$ & $\begin{array}{r}0.097 \\
(3.59)\end{array}$ & $\begin{array}{l}0.098 \\
(2.86)\end{array}$ & $\begin{array}{r}0.179 \\
(3.88)\end{array}$ & $\begin{array}{r}0.211 \\
(5.18)\end{array}$ & $\begin{array}{r}0.421 \\
(7.65)\end{array}$ & $\begin{array}{r}0.181 \\
(6.69)\end{array}$ & $\begin{array}{r}0.211 \\
(6.70)\end{array}$ & $\begin{array}{r}0.025 \\
(0.81)\end{array}$ & $\begin{array}{r}0.080 \\
(1.17)\end{array}$ & $\begin{array}{r}0.031 \\
(0.85)\end{array}$ & $\begin{array}{r}0.145 \\
(1.03)\end{array}$ & $\begin{array}{r}0.034 \\
(1.61)\end{array}$ & $\begin{array}{r}0.093 \\
(1.82)\end{array}$ \\
\hline$\lambda \gamma_{5}$ & $\begin{array}{r}0.005 \\
(0.18)\end{array}$ & $\begin{array}{c}0.005 \\
(0.19)\end{array}$ & $\begin{array}{r}0.132 \\
(4.05)\end{array}$ & $\begin{array}{r}0.179 \\
(4.26)\end{array}$ & $\begin{array}{r}0.127 \\
(3.42)\end{array}$ & $\begin{array}{r}0.219 \\
(4.55)\end{array}$ & $\begin{array}{r}0.147 \\
(5.61)\end{array}$ & $\begin{array}{r}0.175 \\
(5.51)\end{array}$ & $\begin{array}{r}0.006 \\
(0.21)\end{array}$ & $\begin{array}{r}-0.005 \\
(0.07)\end{array}$ & $\begin{array}{r}0.031 \\
(0.91\}\end{array}$ & $\begin{array}{r}0.091 \\
(0.82)\end{array}$ & $\begin{array}{r}0.017 \\
(1.36)\end{array}$ & $\begin{array}{l}0.014 \\
(0.28)\end{array}$ \\
\hline$\lambda \gamma_{6}$ & $\begin{array}{r}-0.069 \\
(3.31)\end{array}$ & $\begin{array}{c}-0.113 \\
(4.64)\end{array}$ & $\begin{array}{r}-0.050 \\
(1.70)\end{array}$ & $\begin{array}{r}0.021 \\
(0.55)\end{array}$ & $\begin{array}{c}0.098 \\
(2.81)\end{array}$ & $\begin{array}{r}0.144 \\
(3.25)\end{array}$ & $\begin{array}{c}0.069 \\
(2.71)\end{array}$ & $\begin{array}{c}0.119 \\
(3.89)\end{array}$ & $\begin{array}{c}0.024 \\
(0.83)\end{array}$ & $\begin{array}{r}0.023 \\
(0.38)\end{array}$ & $\begin{array}{c}0.002 \\
(0.07)\end{array}$ & $\begin{array}{r}-0.076 \\
(0.70)\end{array}$ & $\begin{array}{c}0,015 \\
(0.82)\end{array}$ & $\begin{array}{r}-0.044 \\
(0.93)\end{array}$ \\
\hline $\begin{array}{l}R^{2} \\
S E \\
D W \\
\text { No. obs. } \\
\text { Wald } \\
F^{\mathrm{c}}\end{array}$ & $\begin{array}{c}0.780 \\
78.3 \\
2.20 \\
419 \\
55.27^{*} \\
2.12^{* *}\end{array}$ & $\begin{array}{c}0.791 \\
76.3 \\
2.27 \\
419 \\
42.99^{*} \\
\end{array}$ & $\begin{array}{c}0.503 \\
18.6 \\
2.21 \\
419 \\
11.33 \\
7.38^{* *}\end{array}$ & $\begin{array}{c}0.530 \\
18.1 \\
2.06 \\
419 \\
17.63 \\
-\end{array}$ & $\begin{array}{c}0.267 \\
56.2 \\
1.61 \\
465 \\
11.41 \\
8.25 * *\end{array}$ & $\begin{array}{c}0.315 \\
54.3 \\
1.38 \\
465 \\
8.66 \\
-\end{array}$ & $\begin{array}{c}0.855 \\
36.8 \\
1.37 \\
195 \\
78.11^{*} \\
16.88^{* *}\end{array}$ & $\begin{array}{c}0.839 \\
38.6 \\
1.32 \\
195 \\
82.39^{*} \\
-\end{array}$ & $\begin{array}{c}0.487 \\
442.7 \\
1.73 \\
471 \\
4.71 \\
0.34\end{array}$ & $\begin{array}{c}0.468 \\
450.9 \\
1.72 \\
471 \\
5.90 \\
-\end{array}$ & $\begin{array}{c}0.257 \\
159.6 \\
2.00 \\
471 \\
5.44 \\
0.57\end{array}$ & $\begin{array}{c}0.144 \\
171.3 \\
2.03 \\
471 \\
8.35 \\
-\end{array}$ & $\begin{array}{c}0.243 \\
105.6 \\
1.67 \\
471 \\
19.84^{*} \\
0.71\end{array}$ & $\begin{array}{c}0.215 \\
107.6 \\
1.73 \\
471 \\
16.16 \\
\end{array}$ \\
\hline $\begin{array}{l}\text { Implied } \\
\text { production } \\
\text { smoothing }\end{array}$ & 0.709 & 0.745 & 0.901 & 0.954 & 0.731 & 0.672 & 0.364 & 0.348 & 0.656 & 0.663 & 0.546 & 0.556 & 0.839 & 0.807 \\
\hline
\end{tabular}

${ }^{\mathrm{a}}$ See footnotes under second part of the table. 
Table 2 (continued) ${ }^{\mathrm{a}}$

\begin{tabular}{|c|c|c|c|c|c|c|c|c|}
\hline \multirow{3}{*}{$\begin{array}{c}\text { Estimates } \\
\text { of: }\end{array}$} & \multicolumn{6}{|c|}{ Department of Commerce data } & & \\
\hline & \multicolumn{2}{|c|}{ Tobacco } & \multicolumn{2}{|c|}{ Rubber } & \multicolumn{2}{|c|}{$\begin{array}{l}\text { Stone, Clay, } \\
\text { Glass }\end{array}$} & \multicolumn{2}{|c|}{$\begin{array}{l}\text { Primary } \\
\text { Metals }\end{array}$} \\
\hline & (A) & (B) & (A) & (B) & (A) & (B) & (A) & (B) \\
\hline$\lambda \gamma_{0} \beta_{0}$ & $\begin{array}{l}53.2 \\
(1.07)\end{array}$ & $\begin{array}{l}66.4 \\
(1.05)\end{array}$ & $\begin{array}{c}-36.3 \\
(1.70)\end{array}$ & $\begin{array}{c}-53.9 \\
(2.05)\end{array}$ & $\begin{array}{c}-65.1 \\
(2.47)\end{array}$ & $\begin{array}{c}-78.5 \\
(2.27)\end{array}$ & $\begin{array}{c}-49.3 \\
(0.87)\end{array}$ & $\begin{array}{c}-2.7 \\
(0.04)\end{array}$ \\
\hline$\lambda$ & $\begin{array}{r}0.924 \\
(18.01)\end{array}$ & $\begin{array}{r}1.117 \\
(15.37)\end{array}$ & $\begin{array}{r}1.040 \\
(33.00)\end{array}$ & $\begin{array}{r}1.050 \\
(36.07)\end{array}$ & $\begin{array}{r}0.962 \\
(38.82)\end{array}$ & $\begin{array}{r}0.989 \\
(41.12)\end{array}$ & $\begin{array}{r}0.879 \\
(32.71)\end{array}$ & $\begin{array}{r}0.887 \\
(37.86)\end{array}$ \\
\hline$\lambda \gamma_{0}$ & $\begin{array}{r}0.317 \\
(7.20)\end{array}$ & $\begin{array}{r}0.281 \\
(5.22)\end{array}$ & $\begin{array}{l}0.0649 \\
(2.76)\end{array}$ & $\begin{array}{c}0.0682 \\
(2.71)\end{array}$ & $\begin{array}{c}0.0641 \\
(3.99)\end{array}$ & $\begin{array}{l}0.0429 \\
(2.33)\end{array}$ & $\begin{array}{c}0.0178 \\
(2.81)\end{array}$ & $\begin{array}{l}0.0118 \\
(1.75)\end{array}$ \\
\hline$\lambda \gamma_{0} \beta_{l}$ & $\begin{array}{c}-0.025 \\
(0.25)\end{array}$ & $\begin{array}{c}-0.062 \\
(0.49)\end{array}$ & $\begin{array}{r}0.077 \\
(2.48)\end{array}$ & $\begin{array}{c}0.088 \\
(2.57)\end{array}$ & $\begin{array}{r}0.070 \\
(3.20)\end{array}$ & $\begin{array}{r}0.066 \\
(2.49)\end{array}$ & $\begin{array}{r}0.023 \\
(1.70)\end{array}$ & $\begin{array}{c}0.010 \\
(0.58)\end{array}$ \\
\hline$\lambda \gamma_{1}$ & $\begin{array}{r}0.009 \\
(0.08)\end{array}$ & $\begin{array}{r}0.080 \\
(0.37)\end{array}$ & $\begin{array}{r}0.120 \\
(4.23)\end{array}$ & $\begin{array}{c}0.129 \\
(2.67)\end{array}$ & $\begin{array}{c}0.206 \\
(8.56)\end{array}$ & $\begin{array}{r}0.309 \\
(10.04)\end{array}$ & $\begin{array}{r}0.053 \\
(3.25)\end{array}$ & $\begin{array}{c}0.119 \\
(3.66)\end{array}$ \\
\hline$\lambda \gamma_{2}$ & $\begin{array}{c}-0.264 \\
(2.32)\end{array}$ & $\begin{array}{r}-0.589 \\
(4.00)\end{array}$ & $\begin{array}{c}0.182 \\
(4.88)\end{array}$ & $\begin{array}{l}0.126 \\
(2.43)\end{array}$ & $\begin{array}{r}0.262 \\
(10.93)\end{array}$ & $\begin{array}{r}0.253 \\
(8.83)\end{array}$ & $\begin{array}{l}0.062 \\
(2.64)\end{array}$ & $\begin{array}{l}0.040 \\
(1.17)\end{array}$ \\
\hline$\lambda \gamma_{3}$ & $\begin{array}{r}-0.369 \\
(3.23)\end{array}$ & $\begin{array}{c}-0.610 \\
(3.86)\end{array}$ & $\begin{array}{r}0.157 \\
(3.81)\end{array}$ & $\begin{array}{r}0.099 \\
(1.75)\end{array}$ & $\begin{array}{r}0.197 \\
(7.99)\end{array}$ & $\begin{array}{r}0.213 \\
(7.64)\end{array}$ & $\begin{array}{c}0.008 \\
(0.35)\end{array}$ & $\begin{array}{c}-0.020 \\
(0.58)\end{array}$ \\
\hline$\lambda \gamma_{4}$ & $\begin{array}{c}-0.147 \\
(1.32)\end{array}$ & $\begin{array}{c}0.009 \\
(0.06)\end{array}$ & $\begin{array}{r}0.159 \\
(4.48)\end{array}$ & $\begin{array}{r}0.127 \\
(2.60)\end{array}$ & $\begin{array}{r}0.226 \\
(10.82)\end{array}$ & $\begin{array}{r}0.260 \\
(10.90)\end{array}$ & $\begin{array}{r}0.025 \\
(1.11)\end{array}$ & $\begin{array}{r}0.024 \\
(0.74)\end{array}$ \\
\hline$\lambda \gamma_{5}$ & $\begin{array}{r}0.042 \\
(0.40)\end{array}$ & $\begin{array}{r}0.415 \\
(2.18)\end{array}$ & $\begin{array}{l}0.131 \\
(3.75)\end{array}$ & $\begin{array}{r}0.061 \\
(1.51)\end{array}$ & $\begin{array}{c}0.092 \\
(4.47)\end{array}$ & $\begin{array}{c}0.087 \\
(3.83)\end{array}$ & $\begin{array}{r}0.001 \\
(0.04)\end{array}$ & $\begin{array}{r}-0.021 \\
(0.72)\end{array}$ \\
\hline$\lambda \gamma_{6}$ & $\begin{array}{r}0.017 \\
(0.19)\end{array}$ & $\begin{array}{r}0.207 \\
(1.09)\end{array}$ & $\begin{array}{c}0.093 \\
(2.88)\end{array}$ & $\begin{array}{c}0.030 \\
(0.90)\end{array}$ & $\begin{array}{c}0.126 \\
(6.21)\end{array}$ & $\begin{array}{c}0.139 \\
(6.19)\end{array}$ & $\begin{array}{r}-0.075 \\
(3.19)\end{array}$ & $\begin{array}{c}-0.140 \\
(5.17)\end{array}$ \\
\hline $\begin{array}{l}R^{2} \\
S E \\
D W \\
\text { No. obs. } \\
\text { Wald }^{\mathrm{b}} \\
F^{\mathrm{c}}\end{array}$ & $\begin{array}{c}0.666 \\
45.2 \\
1.85 \\
291 \\
12.10 \\
2.89^{* *}\end{array}$ & $\begin{array}{c}0.622 \\
48.1 \\
1.68 \\
291 \\
29.61 * \\
-\end{array}$ & $\begin{array}{c}0.855 \\
50.2 \\
1.17 \\
291 \\
4.89 \\
5.43^{* *}\end{array}$ & $\begin{array}{c}0.856 \\
50.0 \\
1.14 \\
291 \\
6.21 \\
-\end{array}$ & $\begin{array}{c}0.868 \\
40.3 \\
1.66 \\
291 \\
11.03 \\
37.13^{* *}\end{array}$ & $\begin{array}{c}0.856 \\
42.2 \\
1.56 \\
291 \\
7.48 \\
-\end{array}$ & $\begin{array}{c}0.815 \\
132.0 \\
1.19 \\
291 \\
15.75 \\
6.04^{* *}\end{array}$ & $\begin{array}{c}0.840 \\
123.0 \\
1.23 \\
291 \\
16.40 \\
-\end{array}$ \\
\hline $\begin{array}{l}\text { Implied } \\
\text { production } \\
\text { smoothing }\end{array}$ & 1.024 & 1.412 & 1.044 & 1.015 & 0.699 & 0.621 & 0.936 & 0.978 \\
\hline
\end{tabular}

${ }^{\mathrm{a}}$ Column (A) results are based on assumption that $\mathrm{E}_{t} s_{t+i}=s_{t+i-12}, i=1,2, \ldots, 6$; column (B) results on assumption that expectations are rational. See text for discussion of the implied production smoothing figures.

${ }^{\mathrm{b}}$ Wald $=$ Wald statistic for test of structural stability between the two halves of the sample; * means that the hypothesis of stability is rejected at the 5 percent level.

${ }^{c} F=F$ statistic for test of the hypothesis that $\gamma_{1}=\gamma_{2}=\gamma_{3}=\gamma_{4}=\gamma_{5}=\gamma_{6}=0$; ** means that the hypothesis is rejected at the 5 percent level. 
stability. The results for Cigars are also good. The results for Cigarettes suffer from a negative value for $\beta_{1}$ and failure of the structural stability test. The results for Copper Refining, Lead Refining, and Slab Zinc are the least good. The only good estimate is the estimate of $\lambda$. There is not much support for eqs. (5) and (6) for these three industries, although there is for eq. (7) because of the estimates of $\lambda$.

Consider now the results using the DC data in table 2. The results for Stone, Clay, and Glass and for Primary Metals are good. The estimates of $\lambda$ and $\lambda \gamma_{0}$ are positive and significant, and the implied estimates of $\beta_{1}$ are positive. The expected future sales variables are highly significant, and the Wald test accepts the hypothesis of structural stability. For the Tobacco and Rubber industries the estimates of $\lambda$ are greater than one (except for hypothesis A for Tobacco), and for Tobacco the implied estimates of $\beta_{1}$ are negative. The expected future sales variables are significant, although the most significant coefficient estimates are negative for Tobacco. The hypothesis of structural stability is accepted except for hypothesis B for Tobacco.

\section{Implied production-smoothing behavior}

Do the estimated equations in table 2 imply production smoothing behavior? This question can be examined in the following manner. Consider hypothesis A first. Given this hypothesis and given values of $y_{t-1}, V_{t-1}$, $s_{t}, s_{t-1}, \ldots, s_{t-12}$, an estimated equation can be used to solve for $y_{t} . V_{t}$ can then be solved for using the formula $V_{t}=V_{t-1}+y_{t} D_{t}-s_{t} D_{t}$, where $D_{t}$ is the number of working days in the month. Given these values and given a value for $s_{t+1}$, one can solve for $y_{t+1}$ and then $V_{t+1}$. This process can be repeated throughout the sample period. This is a dynamic simulation of the estimated equation given the actual sales path. The predicted values of $y$ from this simulation are the values that the firm would choose using the estimated decision rule and the given sales path. A similar procedure was followed for hypothesis B. In this case the actual future sales values were used for the expectations. ${ }^{16}$

Having run a dynamic simulation, one can then compare the predicted production path with the actual sales path to see which is smoother. This is done at the bottom of table 2 . The 'implied production-smoothing' figure in each case is the ratio of the variance of detrended predicted production to the variance of detrended actual sales. ${ }^{17}$ In every case for the physical-units data the ratio is less than one, and so the estimated decision equations imply

\footnotetext{
${ }^{16}$ For this exercise it does not really matter what sales path is used. The exercise is to see what a decision equation predicts production to be for some sales path and then to compare the predicted production path to the particular sales path. The actual sales path is obviously a convenient and informative path to use, but other paths could also be used.

${ }^{17}$ The same detrending procedure was used here as was used for the results in table 1.
} 
production-smoothing behavior. For the DC data the results for Stone, Clay, and Glass and for Primary Metals imply production smoothing, but the results for Tobacco and Rubber do not. ${ }^{18}$

It is important to note that the production-smoothing figures at the bottom of table 2 are not dependent on the specification of eqs. (5)-(7) being correct. These equations impose no restrictions on the linearized version of eq. (4), and so the results in table 2 are simply estimates of the linearized version of eq. (4).

It is also important to be clear on what the production-smoothing figures do and do not show. The predicted values from the equations show what production would be if firms followed the equations exactly. Given sales, firms deterministically determine production. If instead there are production shocks or decision errors on the part of the firms, then actual production will deviate from that predicted by the decision rule. These shocks and errors are likely to lead to actual production being more variable than production predicted from the rule. (For all but Cement, predicted production in table 2 is smoother relative to sales than is actual production in table 1.) If the shocks and errors are roughly equal to the estimated errors of the equations, then one is roughly back to comparing actual production to actual sales, which is done in table 1.

\section{Conclusion}

The results in table 1 show that the physical-units data support the production-smoothing hypothesis and that the Department of Commerce data appear to be biased against the hypothesis. The results in table 2 show that the estimated decision equations based on physical-units data imply production smoothing. For four of the seven physical-units industries quite strong effects of expected future sales on current production decisions were picked up. Even the estimated decision equations using Department of Commerce data imply production-smoothing behavior for two of the four industries, and for one of the two industries where production-smoothing behavior is not implied Tobacco - the Department of Commerce data seem particularly bad. The overall results in this paper are thus quite supportive of the productionsmoothing hypothesis, and they help show why negative results using Department of Commerce data have been obtained in the past. This paper also shows that sensible results can be obtained from the approach of estimating approximations to the decision equations. Given the mixed results that have been obtained in the literature estimating Euler equations, estimating decision-equation approximations appears to be a useful alternative.

\footnotetext{
${ }^{18}$ The equations in table 2 for the physical-units data were also estimated over the same sample period used for the DC data (except for Cement). In every case the estimated equations implied production smoothing. The implied production-smoothing numbers were: 0.737 for Cigarettes, 0.849 for Cigars, 0.633 for Tires, 0.611 for Copper Refining, 0.639 for Lead Refining, and 0.762 for Slab Zinc.
} 


\section{Data appendix}

\section{Cigarettes and Cigars}

Data from the Department of Treasury, Bureau of Alcohol, Tobacco, and Firearms. Data collected for the period January 1952 to August 1988. Estimation period: February 1953 to December 1987. Break at December 1969 for the Wald test. Units are in millions for cigarettes and in hundreds of thousands for cigars. Small and large cigars are added together. Data on $Y$ and $S$ collected. Benchmark values used to construct $V$ were 148964 in December 1987 for cigarettes and 7733 in December 1987 for cigars.

\section{Tires}

Data from the Rubber Manufacturers' Association. Data collected for the period January 1947 to June 1987. Estimation period: February 1948 to October 1986. Break at December 1966 for the Wald test. Units are thousands of tires - passenger car plus truck and bus tíres. Data on $Y, S$, and $V$ collected.

\section{Cement}

Data from the Bureau of Mines. Data collected for the period January 1947 to December 1964. (The Bureau of Mines ended its publication of these data in 1964.) Estimation period: February 1948 to April 1964. Break at December 1955 for the Wald test. Units are thousands of barrels. Data on $Y$ and $V$ collected.

\section{Copper Refining, Lead Refining, Slab Zinc}

Data from past issues of Metal Statistics. Data collected for the period January 1947 to December 1987. Estimation period: February 1948 to April 1987. Break at December 1966 for the Wald test. Units are in tons. Data on $Y$ and $V$ collected for Copper and on $Y, S$, and $V$ for Lead and Zinc.

\section{Department of Commerce Data}

Data obtained from Miron and Zeldes (1988b). Data collected for the period February 1959 to December 1984. Estimation period: February 1960 to April 1984. Break at December 1971 for the Wald test. Data on $Y$ and $S$ collected from Miron and Zeldes. Data on $V$ constructed from the data on $Y$ and $S$ using benchmark values of zero in February 1959. Benchmark errors are absorbed in the estimates of the constant terms in table 2. The Department 
of Commerce data are approximately adjusted for the number of working days in the month, although the units are such that the appropriate identity is $Y_{t}=S_{t}+V_{t}-V_{t-1}$, not, as for the physical-units data, $y_{t} D_{t}=s_{t} D_{t}+V_{t}-V_{t-1}$. The reason the working-day adjustment is only approximate is the following. Miron and Zeldes start out with data on shipments and the stock of inventories. The shipments data are adjusted for the number of working days, but the inventory-stock data are not. They then use the identity $Y_{t}=S_{t}+V_{t}-V_{t-1}$ to construct the production data. Because the inventory-stock data have not been adjusted for the number of working days, this procedure is not quite right: $Y_{t}$ is not completely adjusted for the number of working days. For present purposes, however, this problem was ignored, and $V_{t}$ was constructed from $S_{t}$ and $Y_{t}$ using the definition.

\section{References}

Andrews, Donald W.K. and Ray C. Fair, 1988, Inference in nonlinear econometric models with structural change, Review of Economic Studies 60, 615-639.

Blanchard, Olivier, 1983, The production and inventory behavior of the American automobile industry, Journal of Political Economy 91, 365-400.

Blinder, Alan, 1981, Retail inventory behavior and business fluctuations, Brookings Papers on Economic Activity, 443-505.

Blinder, Alan, 1986a, Can the production smoothing model of inventory behavior be saved?, Quarterly Journal of Economics 101, 431-453.

Blinder, Alan, 1986b, More on the speed of adjustment in inventory models, Journal of Money, Credit, and Banking 18, 355-365.

Dimelis, Sophia P. and Tryphon Kollintzas, 1989, A linear rational expectations equilibrium model of the American petroleum industry, in: Tryphon Kollintzas, ed., The rational expectations equilibrium inventory model (Springer-Verlag. New York, NY) 110-197.

Fair, Ray C., 1969, The short-run demand for workers and hours (North-Holland, Amsterdam).

Fair, Ray C., 1971, Sales expectations and short-run production decisions, Southern Economic Journal 37, 267-275.

Ghali, Moheb, 1987, Seasonality, aggregation, and testing of the production smoothing hypothesis, American Economic Review 77, 464-469.

Hansen, Lars, 1982, Large sample properties of generalized method of moments estimators, Econometrica 50, 1029-1054.

Hayashi, Fumio and Christopher Sims, 1983, Nearly efficient estimation of time series models with predetermined, but not exogenous, instruments, Econometrica 51, 783-798.

Krane, Spencer D. and Steven N. Braun, 1989, Production smoothing evidence from physicalproduct data, Mimeo., June.

Miron, Jeffrey A. and Stephen P. Zeldes, 1988a, Seasonality, cost shocks, and the production smoothing model of inventories, Econometrica 56, 877-908.

Miron, Jeffrey A. and Stephen P. Zeldes, 1988b, Production, sales, and the change in inventories: An identity that doesn't add up, NBER working paper no. 2765, Nov.

Ramey, Valerie A., 1988, Non-convex costs and the behavior of inventories, Mimeo., June.

West, Kenneth D., 1986, A variance bounds test of the linear quadratic inventory model, Journal of Political Economy 94, 374-401. 